Journal of Clinical Investigation

Vol. 41, No. 7, 1962

\title{
THE FORMATION OF MACROGLOBULIN ANTIBODIES. I. STUDIES ON ADULT HUMANS *
}

\author{
By JOSEPH LoSPALLUTO, $\dagger$ WILLIAM MILLER, JR., BARBARA DORWARD \\ AND CHESTER W. FINK
}

(From the Departments of Internal Medicine [Rheumatic Diseases Unit], Biochemistry, and Pediatrics, The University of Texas Southwestern Medical School, Dallas, Tex.)

(Submitted for publication January 2, 1962; accepted March 15, 1962)

The occurrence of antibodies of different molecular size in man and experimental animals has long been known (1). In recent years increasing attention has been focused on the group with high molecular weight (19S), which includes not only a number of well defined antibodies but, in addition, certain substances with similar electrophoretic and ultracentrifugal characteristics that are not firmly established as antibodies. Both groups have been discussed by Kunkel, Fudenberg and Ovary $(2,3)$.

Although numerous immunoglobulins in human serum are found either in the $7 \mathrm{~S}$ or $19 \mathrm{~S}$ class of $\gamma$-globulins, certain antibody activities are found in both classes. Among these are the isoagglutinins (3), Wassermann antibodies (4), and lupus factors (5). In addition, antibodies to typhoid $\mathrm{H}$ antigen have recently been found in both the $7 \mathrm{~S}$ and the 19S fractions in the sera of neonatal infants and adults $(6,7)$.

In the course of an investigation of the immune response to typhoid and paratyphoid antigens (8) in patients with a variety of diseases, it was observed that the individuals tested could be placed in one of three categories with respect to the size of the antibodies produced. One group produced only the 7S type; a second, only the 19S type; and a third, a mixture of the two. This distribution is similar to that found for saline anti-A isoagglutinins in different individuals (3). This study was undertaken to elucidate the factors governing the formation of one or the other type of antibody and the interrelationship, if any, of the two types.

\footnotetext{
* Supported by a grant to the Arthritis Clinical Study Center, Parkland Memorial Hospital, from the National Foundation; and by Grant A-2071 from the National Institute of Arthritis and Metabolic Diseases, Bethesda, Md. $\dagger$ Fellow, The Helen Hay Whitney Foundation.
}

\section{MATERIALS AND METHODS}

Most of the individuals were immunized by three injections at weekly intervals of mixed typhoid and paratyphoid vaccine (Lederle), some of $0.5 \mathrm{ml}$ intramuscularly, and others of $0.1 \mathrm{ml}$ intradermally. Blood was drawn 1 week after the last injection, allowed to clot at $37^{\circ} \mathrm{C}$, and the serum collected and stored in a freezer until ready for fractionation and testing.

Five $\mathrm{ml}$ of serum was dialyzed against $3 \mathrm{~L}$ of $0.01 \mathrm{M}$ $\mathrm{Na}_{2} \mathrm{HPO}_{4}, \mathrm{pH} 8.5$ to 9.0 , for 2 days before chromatographic fractionation. Chromatographic separation was carried out on diethylaminoethyl (DEAE)-cellulose columns as described previously (9). The fractions comprising each peak were pooled and tested for antibodies to typhoid $\mathrm{O}$, typhoid $\mathrm{H}$, and paratyphoids $\mathrm{A}$ and $\mathrm{B}$ by standard agglutination procedures (10). Antibody activities associated with the first $(\mathrm{pH} 7.0,0.01 \mathrm{M})$ and the last $(\mathrm{pH} 5.0,0.3 \mathrm{M})$ chromatographic peaks were considered to contain $7 \mathrm{~S}$ and $19 \mathrm{~S} \gamma$-globulins, respectively, on the basis of the behavior of these proteins on DEAE-cellulose $(9,11,12)$. Although the first, or $7 \mathrm{~S}$, peak contains no $19 \mathrm{~S}$ globulins, the last peak is contaminated by 7S protein, which could account for part of the antibody titers associated with this fraction. The results of treatment with mercaptoethanol indicate, however, that virtually all of the activity of the $\mathrm{pH} 5$ peak is in the 19S fraction.

The effect of 2-mercaptoethanol (ME) on agglutinin activity was tested at a number of concentrations and at different temperatures and times. The following procedure was finally adopted. Isotonic saline-phosphate buffer, $\mathrm{pH} 7.0$, containing $0.05 \mathrm{M} 2-\mathrm{ME}$ was prepared. All dilutions of sera and chromatographic fractions for testing were carried out in this buffer. The suspensions of test organisms were also diluted $1: 10$ in the same buffer. Agglutination tests without ME were carried out simultaneously.

Some subjects were given booster injections of the mixed vaccine 3 to 15 months after the initial series. In these cases blood was obtained before administration of the antigen, as well as 1 week later.

\section{RESULTS}

The chromatographic pattern of the serum from a normal individual obtained 1 week after the last 


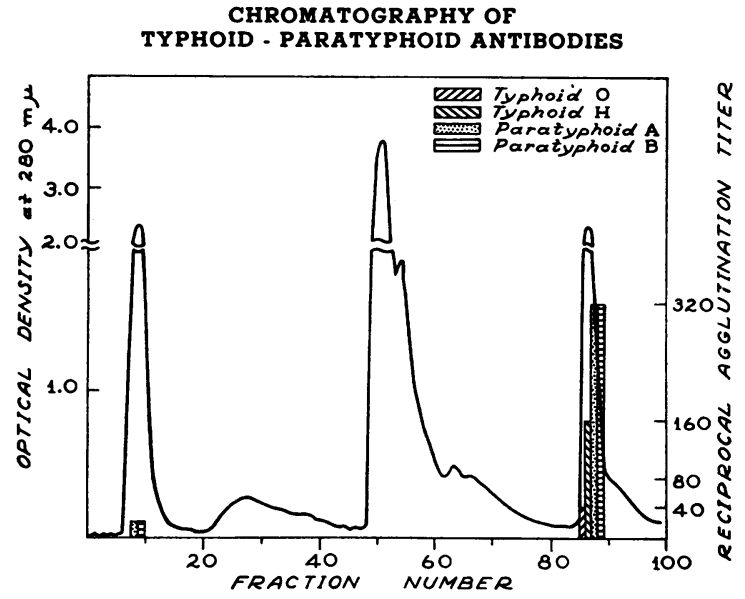

Fig. 1. Chromatographic Pattern of SERUM From A NORMAL INDIVIDUAL (J.L.) 1 MONTH AFTER IMMUNIZATION WITH TYPHOID-PARATYPHOID VACCINE. Five $\mathrm{ml}$ serum on $7.5 \mathrm{~g}$ DEAE-cellulose. Peak I, fractions 1-20 eluted at $\mathrm{pH} 7,0.01 \mathrm{M}$ phosphate. Peak II, fractions

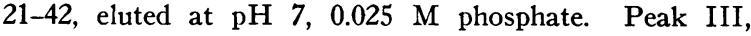

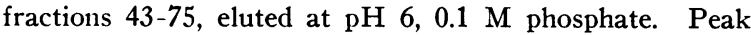
IV, fractions 76-99, eluted at $\mathrm{pH} 5,0.15 \mathrm{M}$ phosphate $+0.15 \mathrm{M} \mathrm{NaCl}$.

of three weekly intramuscular injections of $0.5 \mathrm{ml}$ of mixed typhoid-paratyphoid vaccine is shown in Figure 1. Essentially all of the agglutinin activity for each of the antigens was found in the pooled 19S-containing fraction (peak 4). The distribution of antibody activity seen in Figure 1 represents one of three types seen in an initial survey of different individuals. The distribution of titers in three characteristic subjects is shown in Table I. One of these (J.B.), who produced almost entirely $7 \mathrm{~S}$ antibody, had been initially immunized 15 years earlier. He had received a booster injection 2 years previously and a second booster injection of $0.1 \mathrm{ml}$ of mixed vaccine intradermally.
Another (J.Be.) produced both $7 \mathrm{~S}$ and $19 \mathrm{~S}$ antibodies 1 week after a similar booster injection. He had been immunized initially 8 years earlier. The third (P.C.) produced only 19S antibody 1 month after a single dose of $0.1 \mathrm{ml}$ vaccine administered intradermally. She had not been previously immunized.

In order to investigate the causes of the heterogeneity of antibody size seen in Table I, a group of subjects was immunized under different conditions and by different routes. In 9 normal individuals and 21 patients with a variety of diseases who were immunized for the first time, the antibodies produced 1 week after the last of three intramuscular or intradermal injections were predominantly of the $19 \mathrm{~S}$ class (Table II). There was no history of typhoid or paratyphoid fever in these subjects. The titers in Table II indicate that, while high titers of $19 \mathrm{~S}$ antibodies against all four antigens were present, little 7S antibody was produced in the 1-month period after start of immunization.

In all of these, no qualitative difference was observed between subjects immunized by different routes (i.m. or i.d.). The preponderance of $19 \mathrm{~S}$ antibody at this stage of immunization has also been observed in the neonatal infant $(6,7)$. It should also be pointed out that the antibodies to typhoid O have been consistently of the 19S type, whereas considerable variability in the distribution of the other three antibodies has been observed, as noted above.

Thirty-two subjects, 11 normal and 21 with a variety of disorders, were investigated to determine the effect of previous immunization or exposure on the size of the antibody produced. In these subjects booster injections, intramuscular or

TABLE I

Patterns of typhoid-paratyphoid agglutination tests *

\begin{tabular}{|c|c|c|c|c|c|c|c|c|c|c|c|c|}
\hline \multirow[b]{2}{*}{ Chromatographic fraction } & \multicolumn{4}{|c|}{$\begin{array}{l}\text { Initial immunization } \\
\text { P.C. }\end{array}$} & \multicolumn{4}{|c|}{$\begin{array}{l}\text { Booster after } 8 \text { yrs } \\
\text { J.Be. }\end{array}$} & \multicolumn{4}{|c|}{$\begin{array}{l}\text { Booster after } 15 \text { yrs } \\
\text { J.B. }\end{array}$} \\
\hline & O & $\mathbf{H}$ & $\mathrm{A}$ & B & $\mathrm{O}$ & $\mathrm{H}$ & A & B & $\mathrm{O}$ & $\mathbf{H}$ & A & B \\
\hline $\begin{array}{l}\text { pH 7.0, } 0.01 \mathrm{M} \\
\text { (contains } 7 \mathrm{~S} \text { antibody) }\end{array}$ & 0 & 0 & 0 & 0 & $\mathbf{0}$ & 160 & 320 & 320 & 0 & 160 & 160 & 80 \\
\hline $\mathrm{pH} 7.0,0.025 \mathrm{M}$ & 0 & 0 & 0 & 0 & $\mathbf{0}$ & 0 & 0 & 0 & 0 & $\mathbf{0}$ & $\mathbf{0}$ & 0 \\
\hline $\mathrm{pH} 6.0,0.1 \mathrm{M}$ & 0 & 20 & 0 & 0 & 0 & 20 & 10 & 0 & 0 & 0 & 0 & 0 \\
\hline $\begin{array}{l}\text { pH } 5.0,0.3 \mathrm{M} \\
\text { (contains } 19 \mathrm{~S} \text { antibody) }\end{array}$ & 80 & 320 & 80 & 160 & 20 & 40 & 80 & 160 & 20 & 10 & 0 & 10 \\
\hline
\end{tabular}

* Mean reciprocal titers, 1 week after immunization. 
TABLE II

Distribution of typhoid-paratyphoid agglutinins after initial immunization *

\begin{tabular}{|c|c|c|c|c|c|c|c|c|}
\hline \multirow[b]{2}{*}{ Subjects } & \multicolumn{2}{|r|}{ o } & \multicolumn{2}{|c|}{$\mathrm{H}$} & \multicolumn{2}{|c|}{ A } & \multicolumn{2}{|c|}{ B } \\
\hline & $7 \mathrm{~S}$ & $19 S$ & $7 \mathrm{~S}$ & $19 \mathrm{~S}$ & $7 \mathrm{~S}$ & $19 \mathrm{~S}$ & $7 \mathrm{~S}$ & $19 \mathrm{~S}$ \\
\hline $\begin{array}{c}\text { Normals } \\
{[9]}\end{array}$ & 0 & $\begin{array}{c}43 \\
(0-80)\end{array}$ & $\begin{array}{c}14 \\
(0-80)\end{array}$ & $\begin{array}{c}289 \\
(40-640)\end{array}$ & $\begin{array}{c}20 \\
(0-80)\end{array}$ & $\begin{array}{c}320 \\
(80-640)\end{array}$ & $\begin{array}{c}37 \\
(0-160)\end{array}$ & $\begin{array}{c}382 \\
(80-1,280)\end{array}$ \\
\hline $\begin{array}{c}\text { Patients } \\
{[21]}\end{array}$ & 0 & $\begin{array}{c}35 \\
(0-160)\end{array}$ & $\begin{array}{c}20 \\
(0-160)\end{array}$ & $\begin{array}{c}302 \\
(20-640)\end{array}$ & $\begin{array}{c}36 \\
(0-160)\end{array}$ & $\begin{array}{c}450 \\
(20-1,280)\end{array}$ & $\begin{array}{c}42 \\
(0-320)\end{array}$ & $\begin{array}{c}420 \\
(20-1,280)\end{array}$ \\
\hline $\begin{array}{c}\text { Combined } \\
{[30]}\end{array}$ & 0 & $\begin{array}{c}36 \\
(0-160)\end{array}$ & $\begin{array}{c}18 \\
(0-160)\end{array}$ & $\begin{array}{c}300 \\
(20-640)\end{array}$ & $\begin{array}{c}31 \\
(0-160)\end{array}$ & $\begin{array}{c}412 \\
(20-1,280)\end{array}$ & $\begin{array}{c}41 \\
(0-320)\end{array}$ & $\begin{array}{c}410 \\
(20-1,280)\end{array}$ \\
\hline
\end{tabular}

* Mean reciprocal agglutinination titers. Number of subjects in brackets.

intradermal, were given 1 or more years after the initial immunization. Sera from these subjects were collected 1 week after the booster injections. The results (Table III) indicate that the antibodies produced in this group in response to boosters given long after initial immunization were predominantly of the $7 \mathrm{~S}$ variety for typhoid $\mathrm{H}$ and paratyphoid $\mathrm{A}$ and $\mathrm{B}$ antigens. Again, the anti-O activity was confined to the $19 \mathrm{~S}$ fraction.

The data shown in Tables II and III for typhoid $\mathrm{H}$ and paratyphoid $\mathrm{A}$ and $\mathrm{B}$ antigens suggested that the three different patterns of antibody distribution illustrated in Table I represented different stages of immunization in which macroglobulin antibody initially produced was in time followed by 7S antibody. In no subject (Table II) was the 7S antibody titer higher than the $19 \mathrm{~S}$ at the end of 1 month. It was of considerable interest, therefore, to determine whether this sequence of events could be demonstrated and the time intervals determined. In Table IV are shown the results obtained in six normal subjects at 1 and 4 to 6 months after initial immunization. Samples drawn before and after a booster injection given at 4 to 6 months show the change in the character of the response from that observed after initial immunization. It is seen that $7 \mathrm{~S}$ anti- body appeared in significantly higher concentration in response to the secondary or "booster" immunization, while there was no significant rise in the amount of $19 \mathrm{~S}$ fraction. For purposes of comparison, a similar study was conducted in six hospitalized patients over the same time period with similar results. It is noteworthy, in both the normal individuals and in the patient group, that while high titers of the 19S agglutinins were still present after the 4 to 6 months' booster, they were, in all cases, smaller than those present 1 month after immunization.

In a group of premature infants ( 7$)$, there was almost a complete transition of $19 \mathrm{~S}$ to $7 \mathrm{~S}$ antibody within a 3-month period after initial immunization. Other differences have been reported by Smith, Eitzman and Miller (6).

Effect of treatment with 2-mercaptoethanol. The susceptibility of some 19S macrogammaglobulins to degradation by sulfhydryl compounds such as 2-mercaptoethanol has been well documented (3, 13-19). Sera from nine adults obtained immediately after initial immunization with the typhoid-paratyphoid antigens were tested, therefore, after treatment with this compound. The results obtained before and after treatment with $\mathrm{ME}$ are compared in Table V. It is seen

TABLE III

Typhoid and paratyphoid agglutinins in previously immunized subjects *

\begin{tabular}{|c|c|c|c|c|c|c|c|c|}
\hline \multirow[b]{2}{*}{ Subjects } & \multicolumn{2}{|r|}{ o } & \multicolumn{2}{|c|}{$\mathrm{H}$} & \multicolumn{2}{|c|}{ A } & \multicolumn{2}{|c|}{ B } \\
\hline & $7 \mathrm{~S}$ & $19 \mathrm{~S}$ & $7 \mathrm{~S}$ & $19 \mathrm{~S}$ & $7 \mathrm{~S}$ & $19 \mathrm{~S}$ & $7 \mathrm{~S}$ & $19 \mathrm{~S}$ \\
\hline $\begin{array}{c}\text { Normals } \\
{[11]}\end{array}$ & 0 & $\begin{array}{c}29 \\
(0-80)\end{array}$ & $\begin{array}{c}180 \\
(80-320)\end{array}$ & $\begin{array}{c}44 \\
(40-160)\end{array}$ & $\begin{array}{c}193 \\
(40-320)\end{array}$ & $\begin{array}{c}35 \\
(0-320)\end{array}$ & $\begin{array}{c}147 \\
(20-320)\end{array}$ & $\begin{array}{c}37 \\
(0-160)\end{array}$ \\
\hline $\begin{array}{c}\text { Patients } \\
{[21]}\end{array}$ & 0 & $\begin{array}{c}24 \\
(0-160)\end{array}$ & $\begin{array}{c}216 \\
(40-640)\end{array}$ & $\begin{array}{c}74 \\
(10-160)\end{array}$ & $\begin{array}{c}252 \\
(40-1,280)\end{array}$ & $\begin{array}{c}28 \\
(0-80)\end{array}$ & $\begin{array}{c}201 \\
(20-1,280)\end{array}$ & $\begin{array}{c}71 \\
(0-320)\end{array}$ \\
\hline
\end{tabular}

\footnotetext{
* See footnote, Table II.
} 
TABLE IV

Changes in size of typhoid-paratyphoid agglutinins with time in six normal subjects

\begin{tabular}{|c|c|c|c|c|c|c|c|c|}
\hline \multirow{2}{*}{$\begin{array}{c}\text { Time after } \\
\text { immunization }\end{array}$} & \multicolumn{2}{|r|}{ o } & \multicolumn{2}{|c|}{ H } & \multicolumn{2}{|c|}{ A } & \multicolumn{2}{|c|}{ B } \\
\hline & $7 \mathrm{~S}$ & $19 \mathrm{~S}$ & $7 \mathrm{~S}$ & $19 \mathrm{~S}$ & $7 \mathrm{~S}$ & $19 \mathrm{~S}$ & $7 \mathrm{~S}$ & $19 \mathrm{~S}$ \\
\hline months & & & & & & & & \\
\hline 1 & 0 & $\begin{array}{c}47 \\
(40-80)\end{array}$ & $\begin{array}{c}8 \\
(0-20)\end{array}$ & $\begin{array}{c}267 \\
(160-320)\end{array}$ & $\begin{array}{c}27 \\
(10-80)\end{array}$ & $\begin{array}{c}373 \\
(320-640)\end{array}$ & $\begin{array}{c}53 \\
(20-160)\end{array}$ & $\begin{array}{c}480 \\
(160-1,280)\end{array}$ \\
\hline $\begin{array}{c}4-6 \\
\text { (Prebooster) }\end{array}$ & 0 & $\begin{array}{c}33 \\
(20-40)\end{array}$ & $\begin{array}{c}5 \\
(0-20)\end{array}$ & $\begin{array}{c}227 \\
(80-320)\end{array}$ & $\begin{array}{c}11 \\
(0-40)\end{array}$ & $\begin{array}{c}140 \\
(40-320)\end{array}$ & $\begin{array}{c}18 \\
(0-40)\end{array}$ & $\begin{array}{c}123 \\
(20-160)\end{array}$ \\
\hline $\begin{array}{c}4-6 \\
\text { (Postbooster) }\end{array}$ & 0 & $\begin{array}{c}30 \\
(20-40)\end{array}$ & $\begin{array}{c}55 \\
(10-160)\end{array}$ & $\begin{array}{c}152 \\
(80-160)\end{array}$ & $\begin{array}{c}77 \\
(20-160)\end{array}$ & $\begin{array}{c}173 \\
(80-320)\end{array}$ & $\begin{array}{c}73 \\
(40-160)\end{array}$ & $\begin{array}{c}130 \\
(20-320)\end{array}$ \\
\hline
\end{tabular}

that the agglutinating activity of the macroglobulin antibodies tested decreased markedly after treatment with ME. Where 7S antibodies were present, the titers were not significantly affected by this treatment.

\section{DISCUSSION}

Changes in the physical properties of antibodies during the course of immunization have been observed in the past (20-25). Of particular interest has been the evidence (21-27) that rabbit antibodies, produced early after immunization with sheep erythrocytes, are associated with $\gamma$-globulins of greater electrophoretic mobility than are those produced later in the course of immunization. It was also shown in these investigations that soon after immunization the antibodies were of the 19S type, and those formed later fell into the 7S category (26). These observations recently have been confirmed and extended by Bauer and Stavitsky for a number of antigens in the rabbit (28).

In the present studies, antibodies directed against typhoid-paratyphoid antigens appear to be of the 19S variety early after immunization, with additional 7S-type antibodies to the $\mathrm{H}, \mathrm{A}$, and $\mathrm{B}$ antigens appearing in higher concentrations in adult humans after 4 to 6 months have elapsed.
This observation is based upon the chromatographic properties of the agglutinins found in sera obtained at various times after immunization of 1) individuals followed serially and 2) groups of individuals examined at specific times after immunization.

Supporting evidence for the $19 \mathrm{~S}$ character of early antibodies was obtained by means of agglutination tests performed in the presence of 2mercaptoethanol. Agglutinins found in sera obtained shortly after immunization were almost completely inactivated by treatment with $\mathrm{ME}$, while sera obtained later contained sulfhydryl-resistant 7S agglutinins. These findings support the chromatographic data indicating the presence of $19 \mathrm{~S}$ and $7 \mathrm{~S}$ antibodies in eluates obtained at $\mathrm{pH} 5$, $0.3 \mathrm{M}$, and $\mathrm{pH} 7,0.01 \mathrm{M}$, respectively. Thus, if the fraction containing $19 \mathrm{~S}$ also contains $7 \mathrm{~S}$ globulin, the results obtained after ME treatment indicate that this can be only a very small amount and that most of the agglutinins found in this fraction are of the 19S type. More precise characterization of these antibodies would, of course, entail use of the density gradient centrifugation technique.

The appearance of $19 \mathrm{~S}$ antibodies followed by those of the $7 \mathrm{~S}$ variety was observed in response

TABLE V

Effect of 2-mercaptoethanol (ME) on typhoid-paratyphoid agglutinins

\begin{tabular}{|c|c|c|c|c|c|c|c|c|}
\hline \multirow{2}{*}{$\begin{array}{c}\text { Fraction } \\
\text { tested }\end{array}$} & \multicolumn{2}{|r|}{ O } & \multicolumn{2}{|c|}{$\mathrm{H}$} & \multicolumn{2}{|c|}{ A } & \multicolumn{2}{|c|}{ B } \\
\hline & $7 \mathrm{~S}$ & $19 \mathrm{~S}$ & $7 \mathrm{~S}$ & $19 \mathrm{~S}$ & $7 \mathrm{~S}$ & $19 \mathrm{~S}$ & $7 \mathrm{~S}$ & $19 \mathrm{~S}$ \\
\hline $\begin{array}{l}\text { Without } \\
\text { ME }\end{array}$ & 0 & $\begin{array}{c}49 \\
(20-160)\end{array}$ & $\begin{array}{c}8 \\
(0-40)\end{array}$ & $\begin{array}{c}293 \\
(80-640)\end{array}$ & $\begin{array}{c}20 \\
(0-80)\end{array}$ & $\begin{array}{c}382 \\
(80-640)\end{array}$ & $\begin{array}{c}41 \\
(0-160)\end{array}$ & $\begin{array}{c}462 \\
(80-1,280)\end{array}$ \\
\hline $\begin{array}{l}\text { With } \\
\text { ME }\end{array}$ & 0 & $\begin{array}{c}6 \\
(0-20)\end{array}$ & $\begin{array}{c}3 \\
(0-10)\end{array}$ & $\begin{array}{r}19 \\
(0-40)\end{array}$ & $\begin{array}{c}10 \\
(0-40)\end{array}$ & $\begin{array}{r}27 \\
(0-80)\end{array}$ & $\begin{array}{c}23 \\
(0-80)\end{array}$ & $\begin{array}{r}21 \\
(0-40)\end{array}$ \\
\hline
\end{tabular}


to the typhoid $\mathrm{H}$ and paratyphoid $\mathrm{A}$ and $\mathrm{B}$ antigens, but this sequence did not occur with typhoid $\mathrm{O}$ antigen. In the latter case, the agglutinins formed at the outset, as well as those in patients followed for more than 2 years, were entirely of the $19 \mathrm{~S}$ variety. In no serum of more than 150 individuals studied was any $7 \mathrm{~S}$ agglutinin to typhoid $\mathrm{O}$ found. Moreover, in individuals given booster injections of typhoid-paratyphoid vaccine more than 15 years after initial immunization, typhoid $\mathrm{O}$ agglutinins were entirely in the $19 \mathrm{~S}$ fraction, whereas the other antibodies tested were found chiefly among the 7S $\gamma$-globulins.

The underlying reasons for the phenomena described above are not understood. One of the fundamental questions is why some antigens elicit the formation of only 19S antibodies, while others, either directly or after the elaboration of a $19 \mathrm{~S}$ type of antibody, result in 7S antibody formation. Of the known antibodies that remain macroglobulins, most appear to be formed in response to particulate antigens with a relatively high carbohydrate content, e.g., typhoid $\mathrm{O}$ antibody, red cell isoagglutinins, and heterophile antibody. The agglutinins tested in these experiments, including typhoid $\mathrm{O}$ antibody, were also elicited by administration of a series of particulate antigens. It is not clear whether the $19 \mathrm{~S}$ and $7 \mathrm{~S}$ antibodies produced against paratyphoid $\mathrm{B}$, for example, arise in response to different antigens, or whether two separate and distinct antibody-forming processes involving different cell populations (reacting with the same or different antigens) are involved. The evidence from these and companion studies on premature infants (7) suggests that the latter possibility may obtain. In these studies, initial immunization resulted in formation of $19 \mathrm{~S}$ antibodies with little or no 7S antibodies, and secondary immunization was followed by formation of predominantly $7 \mathrm{~S}$ antibody. The presence of only $7 \mathrm{~S}$ antibodies and little or none of the 19S type after booster immunization of some individuals long after primary immunization indicates that the secondary response was restricted to $7 \mathrm{~S}$ antibody formation. The decreased tendency to produce 19S antibodies in these individuals seems best attributed to the stimulation of a cell population producing $7 \mathrm{~S}$ rather than 19S antibodies against the same antigen. It is possible that a secondary $19 \mathrm{~S}$ antibody rise is not generally observed at this time because at the particular time after immunization that $19 \mathrm{~S}$ serum antibodies to their corresponding antigens are not detectable, intracellular or tissue-fixed antibodies may be present in suffcient quantity to bind injected antigens and thus inhibit the anamnestic response. Finally, it is possible that the $19 \mathrm{~S}$ antibody response is easily suppressed by very small concentrations of serum antibody of the $19 \mathrm{~S}$ type, or even of the $7 \mathrm{~S}$ type, according to the mechanism proposed by $\mathrm{Uhr}$ and Baumann (29). This would tend to eliminate the 19S antibody response and permit 7S antibody formation to proceed preferentially.

A salient feature of the antibody response has been observed in corollary studies on premature infants (7). The presence in the infant of maternally transferred antibodies to the $\mathrm{H}, \mathrm{A}$, and $\mathrm{B}$ antigens completely inhibited the response to injected vaccine. While these studies are, as yet, incomplete, the results to date indicate that the antibodies that traverse the placenta into the infant circulation, which are entirely of the $7 \mathrm{~S}$ variety, effectively prevent an immune response to administered vaccine so that neither $19 \mathrm{~S}$ nor $7 \mathrm{~S}$ antibody is produced. It would be expected, if two antigen groups of significantly different characteristics were involved, that the formation of $19 \mathrm{~S}$ serum antibodies would not be inhibited by the 7S antibody present. These results suggest that in humans the antibodies formed at different stages of immunization, although different in size, are directed against the same or very similar antigens. Similar results were obtained in the case of antibodies produced to sheep erythrocytes and other antigens in rabbits (21-28), and to pneumococcus polysaccharides in the horse (30).

It is also of interest that the change in antibody from the $19 \mathrm{~S}$ to the $7 \mathrm{~S}$ type, at least in regard to the antigens used in this investigation, requires a considerable length of time in adults and is rarely complete. In the group of individuals studied from the outset of immunization, blood drawn 1 to 2 years after initial inoculation, while rich in $7 \mathrm{~S}$ antibody, still contained appreciable titers of $19 \mathrm{~S}$ antibodies. Although, in some individuals examined 10 to 15 years after immunization, agglutinins produced on booster injection were chiefly $7 \mathrm{~S}$ globulins with little or no activity present in the 19S fractions, this type of subject 
represented the exception, rather than the rule. In most, while the secondary response consisted, as far as could be detected, essentially of the formation of 7S antibody, there was usually demonstrable 19S activity. The final distribution of antibodies may be governed by factors similar to those that determine the types of saline isoagglutinins in adult humans ( 3 ).

In contrast, the production of $7 \mathrm{~S}$ agglutinins following the $19 \mathrm{~S}$ variety was considerably more rapid in newborn infants, especially after booster immunization. At a point 4 to 6 months after initial immunization, the antibodies in a group of adults were still predominantly in the $19 \mathrm{~S}$ fraction (Table IV), whereas the same agglutinins were found chiefly in the 7S fraction in infants at the same time. Older infants showed an adult-type response. The underlying reasons for the differences between the newborn and the adult are unclear. A possible explanation is discussed elsewhere $(7)$.

The results obtained in these studies with antibodies to the $\mathrm{O}$ antigens confirm the previous description of these antibodies as members of the $19 \mathrm{~S}$ class of globulins (31). On the other hand our data suggest that previous reports, indicating that typhoid $\mathrm{H}$ antibodies are $7 \mathrm{~S}$ proteins $(5,32)$, are oversimplifications.

The present findings demonstrate that both man and experimental animals produce at least two different types of antibody to some antigens, on the basis of physicochemical criteria. Yet others, like typhoid O, may elicit only 19S antibodies even after many years. The relationship of antigenic structure and size to antibody size is as yet unexplored. Differences between types of antigens, which may be responsible for the phenomena observed here, are currently under investigation. Information of this type may lead to an understanding of the events leading to formation of macroglobulin and $7 \mathrm{~S}$ antibodies.

\section{SUM MARY}

1) Normal and diseased subjects produce high molecular weight (19S) antibodies and little or no 7S antibody after initial immunization with typhoid-paratyphoid antigens. Different routes of immunization, whether intramuscular or intradermal, gave qualitatively similar results.
2) After booster injection of subjects immunized at some time in the past, antibodies to typhoid $\mathrm{H}$ and paratyphoids $\mathrm{A}$ and $\mathrm{B}$ are found predominantly in the low molecular weight $(7 \mathrm{~S})$ fraction.

3) Typhoid $O$ agglutinins have been found exclusively in the 19S fraction, and no change in the size of these antibodies occurs with time.

4) The change in the typhoid $\mathrm{H}$ and paratyphoid A and B antibodies from $19 \mathrm{~S}$ to predominantly $7 \mathrm{~S}$ type in adults requires more than 6 months, and few subjects show complete change. In most subjects, $19 \mathrm{~S}$ agglutinins are present even 1 to 2 years after initial immunization, although $7 \mathrm{~S}$ antibodies predominate.

\section{REFERENCES}

1. Kabat, E. A., and Mayer, M. M. Experimental Immunochemistry, 2nd ed. Springfield, Ill., Thomas, 1961, chap. 7.

2. Kunkel, H. G. Macroglobulins and high molecular weight antibodies in The Plasma Proteins, F. W. Putnam, Ed. New York, Academic Press, 1960, vol. I.

3. Kunkel, H. G., Fudenberg, H., and Ovary, Z. High molecular weight antibodies. Ann. N. Y. Acad. Sci. 1960, 86, 966.

4. Franklin, E. C., and Kunkel, H. G. Immunologic differences between the $19 \mathrm{~S}$ and $7 \mathrm{~S}$ components of normal human $\gamma$-globulin. J. Immunol. 1957, 78, 11.

5. Goodman, H. C., Fahey, J. L., Malmgren, R. A., and Brecher, G. Separation of factors in lupus erythematosus serum reacting with components of cell nuclei. Lancet 1959, 2, 382.

6. Smith, R. T., Eitzman, D. V., and Miller, B. Qualitative differences in the immune response of infants and adults receiving Salmonella vaccines (abstract). J. clin. Invest. 1960, 39, 1029.

7. Fink, C. W., Miller, W. E., Jr., Dorward, B., and LoSpalluto, J. The formation of macroglobulin antibodies. II. Studies on neonatal infants and older children. J. clin. Invest. 1962, 41, 1422.

8. LoSpalluto, J., Miller, W., Jr., Fink, C., and Dorward, B. The production of $19 \mathrm{~S}$ antibodies in adults and premature infants (abstract). Arth. Rheum. 1961, 4, 117.

9. LoSpalluto, J., and Ziff, M. Chromatographic studies of the rheumatoid factor. J. exp. Med. 1959, 110, 169.

10. Kolmer, J. A., Spaulding, E. H., and Robinson, H. W. Approved Laboratory Technic, 5th ed. New York, Appleton-Century Crofts, 1951.

11. LoSpalluto, J., Chegoriansky, J., Lewis, A., and Ziff, M. Chromatographic properties of gamma 
globulin: Behavior of serum gamma macroglobulins. J. clin. Invest. 1960, 39, 473.

12. Fahey, J. L., McCoy, P. F., and Horbett, A. P. Chromatographic characterization of the serum protein changes in pathologic sera (abstract). J. clin. Invest. 1958, 37, 893.

13. Deutsch, H. F., and Morton, J. I. Dissociation of human serum macroglobulins. Science 1957, 125, 600.

14. Deutsch, H. F., and Morton, J. I. Human serum macroglobulins and dissociation units. I. Physicochemical properties. J. biol. Chem. 1958, 231, 1107.

15. Grubb, R., and Swahn, B. Destruction of some agglutinins but not of others by two sulfhydryl compounds. Acta path. microbiol. scand. 1958, 43, 305.

16. Heimer, R., and Federico, O. M. Depolymerization of the $19 \mathrm{~S}$ antibodies and the $22 \mathrm{~S}$ rheumatoid factor. Clin. chim. Acta 1958, 3, 496.

17. Glenchur, H., Zinneman, H. H., and Briggs, D. R. Macroglobulinemia: Report of two cases. Ann. intern. Med. 1958, 48, 1055.

18. Deutsch, H. F., and Chan, P. C. Y. Human serum hemagglutinins. Fed. Proc. 1958, 17, 210.

19. Fudenberg, H. H., and Kunkel, H. G. Physical properties of the red cell agglutinins in acquired hemolytic anemia. J. exp. Med. 1957, 106, 689.

20. Paic, M. Ultracentrifugation de l'hémolysine. Détermination de sa constante de sédimentation et de son poids moléculaire. Bull. Soc. Chim. biol. (Paris) 1939, 21, 412.

21. Stelos, P., and Taliaferro, W. H. Separation of antibodies by starch zone electrophoresis. Analyt. Chem. 1959, 31, 845.

22. Stelos, P., and Talmage, D. W. The separation by starch electrophoresis of two antibodies to sheep red cells differing in hemolytic efficiency. $\mathrm{J}$. infect. Dis. 1957, 100, 126.
23. Taliaferro, W. H., and Talmage, D. W. Antibodies in the rabbit with different rates of metabolic decay. J. infect. Dis. 1956, 99, 21.

24. Talmage, D. W., Freter, G. G., and Taliaferro, W. H. The effect of repeated injections of sheep red cells on the hemolytic and combining capacities of rabbit antiserums. J. infect. Dis. 1956, 98, 293.

25. Stelos, P. Electrophoretic and ultracentrifugal studies of rabbit hemolysins. J. Immunol. 1956, 77, 396.

26. Stelos, P. Comparative study of rabbit hemolysins to various antigens. I. Hemolysins to beef red cells. J. infect. Dis. 1958, 102, 103.

27. Stelos, P., and Talmage, W. H. Comparative study of rabbit hemolysins to various antigens. II. Hemolysins to the Forssman antigen of guinea pig kidney, human type $\mathrm{A}$ red cells and sheep red cells. J. infect. Dis. 1959, 104, 105.

28. Bauer, D. C., and Stavitsky, A. B. On the different molecular forms of antibody synthesized by rabbits during the early response to a single injection of protein and cellular antigens. Proc. nat. Acad. Sci. (Wash.) 1961, 47, 1667.

29. Uhr, J. W., and Baumann, J. B. Antibody formation. I. The suppression of antibody formation by passively administered antibody. II. The specific anamnestic antibody response. J. exp. Med. 1961, 113, 935, 959.

30. Kabat, E. A. Immunochemistry of the proteins. J. Immunol. 1943, 47, 513.

31. Deutsch, H. F., Alberty, R. A., and Gosting, L. J. Biophysical studies of blood plasma proteins. IV. Separation and purification of a new globulin from normal human plasma. J. biol. Chem. 1946, 165, 21.

32. Goodman, H. C., Fahey, J. L., and Malmgren, R. A. Serum factors in lupus erythrematosus and other diseases reacting with cell nuclei and nucleoprotein extracts: Electrophoretic, ultracentrifugal and chromatographic studies. J. clin. Invest. 1960, 39, 1595.

\section{SPECIAL NOTICE TO SUBSCRIBERS}

Post Offices will no longer forward the Journal when you move.

Please notify The Journal of Clinical Investigation, Business Office, 10 Stoughton Street, Boston 18, Mass., at once when you have a change of address, and do not omit the zone number if there is one. 